\title{
1. Utility models: do they really serve national innovation strategies?
}

\section{Uma Suthersanen}

\section{INTRODUCTION}

In the past two decades, there has been a growing belief within the intellectual property fraternity about the desirability for and the relevance of a further tier of patentlike protection within the general intellectual property framework. Such laws, usually referred to as utility model laws, are considered to be conducive to innovation and growth in two different economic environments. First, within established, developed economies, alternative sui generis regimes are viewed as a means of ameliorating the shortcomings of patent law, especially in relation to small and medium sized enterprises in nationally important socioeconomic sectors. Second, legal and economic scholars have praised the utility model regime as a necessary facet in promoting a sustainable development space to help struggling economies promote indigenous innovation. ${ }^{1}$

The first two sections of this chapter focus on the legal nature of and justificatory bases for 'utility model' protection. In doing so, the analysis briefly considers the normative economic rationales for protecting innovation under intellectual property law. The next section carries out a chronologically based and comparative analysis of several utility model systems around the world. In adopting this approach, the chapter attempts to determine whether utility models should, in certain predetermined circumstances, be promoted as a more dominant form of intellectual property right in a country or region, as this would enhance development and innovation. It does this by exploring the perceived link between utility model law and innovation from the standpoint of two fundamental queries:

1 The use of the term 'innovation' is akin to the Schumpeterian approach: see J. Schumpeter, Business Cycles, Vol. 1 (New York, NY and London, UK: McGraw-Hill, 1939) 84; and also W. Kingston, The Political Economy of Innovation (The Hague: Springer, 1984) chs 1 and 3. 
(1) Is it valid for a country to introduce a second tier patent law on the basis that the deficiencies of the traditional patent system can be either solved or avoided?

(2) Irrespective of the perceived deficiencies of a patent system, does the utility model law offer a robust ecosystem promoting innovation?

UTILITY MODELS WITHIN THE GLOBAL LEGAL FRAMEWORK

Although the right has been in force in some form or other in several jurisdictions for at least 160 years, patent protection is still far from a widely implemented or harmonised species of law. Approximately 70 countries provide second tier patent protection resembling utility model protection in some form or another, including countries with highly successful innovation strategies, notably Japan, South Korea, China and Germany. Conversely, other countries which manifest a similar economic history of innovation, including the United States, the United Kingdom, Singapore, Sweden and Canada, have not embraced any utility model regime. ${ }^{2}$

\subsection{Characteristics of the 'Utility Model'3}

A quick summation of the law should start by noting that the term 'utility model' has morphed, over the years, into a generic term referring to a second

2 A list of countries and regions with utility model protection can be found on the World Intellectual Property Organization (WIPO) website, available at www.wipo .int/sme/en/ip_business/utility_models/where.htm (accessed 30 September 2018).

3 The following discussion summarises several works, including: C. Heath, 'Utility models in East and West' in Current Problems of Intellectual Property Law - Writings in Honour of Nobuo Monya (Tokyo: Hatsumei kyokei, 1998) 47; M.D. Janis, 'Second tier patent protection' (1999) 40 Harv. Int'l L.J. 151; U. Suthersanen, 'Incremental inventions in Europe: a legal and economic appraisal of second tier patents' (2001) J. Bus. L. 319; U. Suthersanen (2006), 'Utility models and innovation in developing countries', UNCTAD-ICTSD Project on IPRs and Sustainable Development (2006) available at http://unctad.org/en/docs/iteipc20066_en .pdf (accessed 30 September 2018); I. Png and A. Hu, Protection of Sub-Patentable Inventions in Singapore (Singapore: IP Academy, 2014) available at http://docplayer .net/67669096-Protection-of-sub-patentable-inventions-in-singapore.html (accessed 30 September 2018); U. Suthersanen and G. Dutfield, 'Utility models and other alternatives to patents' in U. Suthersanen, G. Dutfield and K.B. Chow (eds), Innovation without Patents: Harnessing the Creative Spirit in a Diverse World (Cheltenham, UK and Northampton, MA: Edward Elgar, 2007) 18; Australian Government, Advisory Council on Intellectual Property, 'Review of the Innovation Patent System' (May 2015) 
tier patent system which offers cheaper protection to subject matter that falls between patent and sui generis design laws. It is ostensibly a registered intellectual property right which confers exclusive protection for a technical invention. It resembles a patent in that the invention must be new and should display a measure of inventive achievement. Unlike patents, however, utility models are often granted without prior examination to establish novelty and/or inventive step. While protection can be obtained more rapidly and cheaply, it will also be commensurately less secure.

There is no universal nomenclature for this type of hybrid right. Australian law, for example, has alternatively referred to them as 'petty patents' and as 'innovation patents'. ${ }^{4}$ They are called 'utility innovations' in Malaysia, 'utility certificates' in France and 'short-term patent' in Belgium, although the prevailing term remains 'utility models', as used in Germany and China. International instruments refer to them synonymously as utility certificates, utility models and utility certificates of addition. ${ }^{5}$ Some systems define utility models as incorporeal subject matter including technical concepts or inventions or devices, while others anchor their definitions to three dimensional forms and exclude plants, methods and biological and pharmaceutical products. A few countries offer second tier protection which adopts normal patent thresholds but without prior examination and for a shorter duration.

From a global perspective, identifiable common traits within national utility model regimes include the following: ${ }^{6}$

(1) The laws confer registered, exclusive rights on the proprietor of the right (as opposed to an anticopying or automatic unregistered right).

(2) Novelty is a criterion in all systems, although the standard of novelty varies from universal novelty to local novelty. ${ }^{7}$

available at www.ipaustralia.gov.au/sites/g/files/net856/f/final_report.pdf (accessed 30 September 2018).

See at 4.3 below.

Art. 2 Patent Cooperation Treaty; Art. 2 Agreement for the International Patent Classification 1971.

$6 \quad$ Suthersanen, Dutfield and Chow (eds), n. 3 above, ch. 3; H.-P. Brack, 'Utility models and their comparison with patents and implications for the US intellectual property law system', Boston College Intellectual Property \& Technology Forum (2009) available at http://bciptf.org/wp-content/uploads/2011/07/13-iptf-Brack.pdf (accessed 30 September 2018).

It is noteworthy that national utility model systems tend to adopt the International Patent Classification (IPC) as provided by the 1971 Strasbourg Agreement for the International Patent Classification, which facilitates the retrieval of patent documents in order to conduct effective novelty searches and determine the state of the art. 
(3) Although registration is a requirement, there is usually no substantive examination of applications.

The major points of divergence are:

Subject matter under protection: Some utility model laws protect only the three dimensional form while others extend the umbrella of protection to cover all technologies and processes but exclude controversial subject matter such as pharmaceutical or biological substances, or plant varieties. ${ }^{8}$ A majority of utility model laws simply adopt the domestic patent law definition of protectable subject matter. The current German Utility Model Act, for example, is the archetypical second tier regime within a developed nation, where protection can extend to all inventions with important exceptions, including methods, processes or biotechnological inventions. ${ }^{9}$

Granting procedure: Many systems adopt a simple registration procedure with cursory examination, while a few implement a detailed examination process. In practice, some examining offices offer an optional detailed search facility with the payment of supplementary fees. Other jurisdictions expressly call for a detailed search on validity to be carried out on the commencement of civil proceedings. ${ }^{10}$

Substantive criteria: Herein lies the greatest disparity between the utility model systems. While all major utility model systems adopt the criterion of novelty, the level of novelty required ranges from universal novelty, to relative novelty, to domestic novelty. A second criterion is usually, though not always, imposed in the form of inventiveness or usefulness. Again, the standard employed for the level of inventiveness varies greatly. There is also a significant propensity within current utility model laws to link the definition of the utility model with an element of industrial application.

Scope of protection: A final element of divergence is the duration of protection, which can vary from 6 years (for example in France), to 10 years (for example, in Germany, South Korea and Spain), to 15 years (Brazil), with varying restrictions on the specifications and claims of the utility model right.

\subsection{International Rules}

The absence of a transnational pattern is reflected in the lack of international norms regarding the nature and extent of a second tier patent regime. For example, Article 1(2) Paris Convention merely states: 'The protection of 
industrial property has as its object patents, utility models, industrial designs, trade marks, service marks, trade names, indications of source or appellations of origin, and the repression of unfair competition.'

Countries are free to formulate or reject utility model protection as they see fit; should a country introduce a utility model regime, it can tailor such a regime to exclusively adapt to local socioeconomic conditions and infrastructure. Nonetheless, it should also be noted that Paris Union countries which have a utility model regime cannot discriminate against a foreign rights holder in terms of recognition and enforcement of such utility models pursuant to the generally applicable national treatment obligation. ${ }^{11}$ Reciprocal national treatment will also apply for select international principles including the right of priority, ${ }^{12}$ the importation and forfeiture clauses, ${ }^{13}$ and the compulsory licensing arrangements. ${ }^{14}$ However, the Paris Convention is silent on the definition, nature and scope of the right and protection. The TRIPS Agreement, by incorporating the main provisions of the Paris Convention, extends the WTO dispute settlement system to utility models; but the Agreement fails to establish any other international benchmark for this form of protection. ${ }^{15}$

A consideration of other international arenas reveals that despite the recalcitrance of international instruments with regard to engagement with utility models, these rights are being increasingly recognised within the intellectual

11 Art. 2(1) Paris Convention for the Protection of Industrial Property of 20 March 1883 (1967, Stockholm revision); G.H.C. Bodenhausen, Guide to the Application of the Paris Convention for the Protection of Industrial Property, as Revised at Stockholm in 1967 (Geneva: WIPO, 1969) 29.

12 Arts 4(E)(1) and 4(E)(2) Paris Convention.

13 Art. 5A Paris Convention.

$14 \quad$ Arts 5D and 11 Paris Convention.

15 Arts 1(2) and 2(1) Agreement on Trade-related Aspects of Intellectual Property Rights, Including Trade in Counterfeit Goods, Annex 1C of the WTO Agreement, 15 April 1994. Other instruments which refer to utility models (as well as inventors' certificates and utility certificates) are the International Patent Classification (IPC) and the Patent Cooperation Treaty (PCT). The latter allows for international applications for both patents and utility models within designated Contracting States. 
property chapters of free trade agreements (FTAs),${ }^{16}$ or as investments under some international investment agreements (IIAs). ${ }^{17}$

\section{3} JUSTIFYING UTILITY MODELS

The traditional premise within market economies is that patents are necessary tools as they confer a protective buffer on inventors against other competitors. The consequent societal welfare is assured: labour is rewarded, the invention is divulged to the public, further technological innovation is stimulated, and a public knowledge base is incrementally strengthened, upon which a society's future technological progress will be built. ${ }^{18}$

Nevertheless, this utopian vision only materialises within certain political, economic and social environments, where intellectual property rights are allowed to act as competitive boosts to innovation and growth. IPRs are often seen as being 'a drain on learning and source of market power that is inimical to development'. ${ }^{19}$ Policy and economic rationales underpin the limits placed on national patent law, ensuring that not all inventive activities are embraced as being worthwhile of protection. Inventions must fulfil certain criteria under a rigorous examination procedure, while other types of subject matter are excluded $a b$ initio from the patent regime so as to support complementary, or sometimes conflicting, policies in maintaining the public domain, competition, health and education. It is now accepted that the monopoly privileges and

16 Examples of FTAs incorporating substantial obligations in relation to utility models include the EU-CARIFORUM European Partnership Agreement and the Japan-Indonesia Economic Partnership Agreement. For an excellent discussion on these two FTAs, see H. Grosse Ruse-Khan, 'The International Legal Framework for the Protection of Utility Models', Max Planck Institute for Intellectual Property \& Competition Law Research Paper No 12-10 (1 October 2012) available at https://papers .ssrn.com/sol3/papers.cfm?abstract_id=2160229 (accessed 30 September 2018).

${ }_{17}$ Examples include the Germany-Pakistan Bilateral Investment Agreement, 2009 - see discussion within H. Grosse Ruse-Khan, Utility Model Protection in Pakistan - An Option for Incentivising Incremental Innovation, WIPO-commissioned report (2 April 2015) 14-15, available at www.ip.mpg.de/fileadmin/ipmpg/content/forschung _aktuell/05_utility_model_protection/wipo_study_on_utility_model_protection_in _pakistan.pdf (accessed 30 September 2018).

18 E. Kitch, 'The Nature and Function of the Patent System' (1977) 20 J. L. \& Econ. 265, 281.

19 K. Maskus, Private Rights and Public Problems: The Global Economics of Intellectual property in the 21st Century (Washington, DC: Peterson Institute for International Economics, 2012) 234. 
exclusivity arising from patents invariably affect other public spheres, and the rigorous eligibility standards are essential to prevent excessive patenting. ${ }^{20}$

So how do we justify the introduction of a sui generis law that potentially undermines the strict demarcations of traditional intellectual property rights? Sui generis rights (such as utility model, design, semiconductor chip, geographical indications or database laws) emanate from the inability of legislators and jurists to stretch the existing three bulwarks of the intellectual property regime to accommodate new things to protect. ${ }^{21}$ The subject matter, criteria and scope of protection of sui generis regimes inevitably reflect copyright, patent or trade mark characteristics, or a mixture of all three types of intellectual property rights. For instance, the novelty criterion betrays the patent origin of plant variety and utility model laws. Geographical indication laws, with their roots in trade protectionism and product identity, adopt a trade mark approach, protecting signs of distinctive qualities and geographical origins. Nevertheless, a constant battle is fought as to the rationale and scope of such rights. In our case, the questions are varied: Should utility model laws protect all innovations which show a modest level of inventiveness and novelty? Should utility model laws be confined to minor innovations in the field of engineering and construction, and exclude more 'advanced' technologies such as computer programs, biotechnology and pharmaceuticals? The following discussion explores such issues by focusing on three main rationales for a sui generis utility model right: (1) ameliorating the defects of the national patent system; (2) preventing free riding copying and encouraging innovation, especially in relation to SMEs; and (3) improving the legal environment in developing countries.

\subsection{Curing Patent Law}

In 1843, the first known second tier patent system was introduced by the United Kingdom's Utility Designs Act in response to criticism of the Victorian British patent system as being administratively complex and causing insuperable costs. The law protected the 'shape or configuration of useful articles of manu-

20 The extensive historical and current literature on the link between intellectual property, public interest and national innovation includes J. Harrison, Encouraging Innovation in the Eighteenth and Nineteenth Centuries: The Society of Arts and Patents, 1754-1904 (Gunnislake: High View, 2006); K. Maskus and J. Reichman (eds), International Public Goods and Transfer of Technology Under a Globalized Intellectual Property Regime (Cambridge: Cambridge University Press, 2005); Maskus, n. 19 above.

${ }^{21}$ See W.R. Cornish, 'The International Relations of Intellectual Property' (1993) 52 Cambridge L.J. 46, 54-55. 
facture'. ${ }^{22}$ In a similar vein, the German utility model system emerged in 1891 as a backlash against the stringent German patentability standards, especially its level of inventive step. ${ }^{23}$ Arguably, the introduction of a sui generis law was perhaps the inevitable solution in these two newly industrialised nations in order to resolve the deficiencies of their patent systems, especially in terms of cost, speed and ease. It is noteworthy that British history continued to show that an ineffective utility model system which fails to grapple with the patent problem is doomed to failure, and by 1919 the British utility model experiment had concluded. Instead, in 1989, Britain eventually dealt with the lacuna in protecting minor innovations through its own national sui generis unregistered design right - a system which protects functional three dimensional shapes, using much lower criteria. $^{24}$

However, from the German perspective (and indeed, as we see below, from the East Asian one), it is unarguable that a sui generis regime is useful in resolving or avoiding the deficiencies of the current patent system, in terms of cost and speed of securing protection and in harnessing and diffusing indigenous technologies. One commentator lists the advantages of utility model registration, in comparison to patents in Germany, as including lower costs, lower thresholds in relation to novelty and inventiveness, quicker registration procedure and strategic means of obtaining full protection during the intermediate period between publication and actual grant of a patent. ${ }^{25}$ This type of reasoning can be easily extrapolated across other established, developed countries.

But is this a sufficient basis for the introduction of yet another intellectual property right, notably as the right in question appears to undermine essential principles of the current patent law? All intellectual property rights are predicated on the notion that inventions and creative works are in the public domain unless such works fulfil various thresholds, such as novelty or inventive step (in the case of patents), originality or distinctiveness (in the cases of copyright or trade mark).

226 \& 7 Vict. ch. 65. See M.D. Janis, ‘Second Tier Patent Protection' (1999) 40 Harv. Int'l L.J. 151, 156; L. Bently and B. Sherman, 'The United Kingdom's Forgotten Utility Model: The Utility Designs Act of 1843' (1997) 3 IPQ 265. For an entertaining (and damning) account of the inefficiencies of the British Patent Office, see C. Dickens, The Poor Man's Tale of a Patent, 1850, reproduced and annotated in J. Phillips, Charles Dickens and the 'Poor Man's Tale of a Patent' (Oxford: ESC Publishing, 1984).

${ }_{23}$ U. Suthersanen, 'Utility models and innovation in developing countries, n. 3 above, 15; P.A. Cummings, 'From Germany to Australia: opportunity for a second tier patent system in the United States' (2010) 18 Mich. St. J. Int'l L. 297, 303.

${ }_{24} \quad$ Sec. 213 et seq., United Kingdom Copyright, Designs and Patents Act 1988.

25 Brack, n. 6 above. 
Partly in deference to the high societal costs imposed by the conferral of a proprietary right, which will stifle competition for a short time, and partly to forestall duplication of patent protection for identical or similar inventions, the examination system is a major element of the patent regime. The justifications of the traditional patent law are reconfirmed during the examination process. Providing second tier rights for inventions that fail to meet such standards undermines both the public-private boundary and the doctrinal bases of intellectual property rights.

The worrying concern is that utility model laws can result in barring the entry of both new and competing substitutive products, ${ }^{26}$ especially in capitalist market based economies, where it is generally accepted that all market actors - including competitors, follow-on creators and consumers - should be allowed to freely use such public domain works which fall short of the required standards. Developing countries, in particular, should be cautious in broadening protection to cover all types of innovations - irrespective of whether they are minor and low cost innovations, or instead involve complex and cutting edge technologies, such as in the case of biological and pharmaceutical products. ${ }^{27}$

Indeed, there is a reasonable concern that larger market players may use utility models as a means of circumventing the more stringent criteria under the patent system and overuse the system in ways that make it hard for SMEs to compete. Certainly, the lack of substantive examination prior to grant will give rise to uncertainty for third parties when conducting infringement searches to ascertain what valid rights exist in a particular field of technology, which may act as an additional barrier to competitors and lead to abusive behaviour by foreign applicants.

Perhaps we should accept that there should be a differentiated patent policy in respect of different types of inventive activities. This was clear, for example, when the failed EU Directive for utility model was under consideration. While condoning lower standards of protection for various inventive activities, the Commission Proposal also excluded protection of biological or pharmaceutical inventions within the utility model system. ${ }^{28}$ This exclusion was rationalised on two grounds: first, such subject matters call for lengthy preparation before being placed on the market and should therefore be given patent protection that lasts longer than utility model protection; second, the Commission conceded

26 F.M. Scherer and D.R. Ross, Industrial Market Structure and Economic Performance (3rd edn, Boston: Houghton Mifflin, 1990) 577-78.

$27 \quad$ Such as utility model laws in Germany and Australia.

28 Art. 4(b) and (c) of the Commission Proposal of 12 December 1997 for a European Parliament and Council Directive approximating the legal arrangements for the protection of inventions by utility model, COM(1997) 691 final. 
that these sectors are complex areas in which property rights involving no examination as to novelty or inventive step are out of place.

The resulting issue, then, is how we distinguish between various innovations. It may be that this will be dependent on the innovative capacity of each country, which in turn will depend on the particular industrial sector in focus.

\subsection{Preventing Free Riding and Promoting SMEs}

The nature of inventive efforts has evolved from technological breakthroughs to a greater focus on inventions that are incremental in nature; broadening patent protection to encompass such incremental innovations can be an accepted patent policy under certain circumstances, especially in encouraging follow-on inventors to secure rights on their cumulative improvements. ${ }^{29}$ A corollary factor is that in some countries, more innovations, both of the breakthrough and incremental varieties, emanate from local small and medium sized enterprises (SMEs) than from larger multinational conglomerates. Such inventions tend to have a lower standard of inventiveness, are prime candidates for free riding activities by competitors and deserve new hybrid intellectual property rights.

It is argued that sui generis regimes have historically improved the legal environment for incremental innovation, and consequently are good for the national economy. A related reason why utility models may be good for SMEs is that the cost factor may inhibit them from using the patent system as much as they would desire.

Should a new property right be the answer to help SMEs? Why should low cost and incremental innovative activities be rewarded with a monopoly right? A forceful objection to inventions which do not entail high transaction or R\&D costs is made by Kitch, who states:

Low-cost inventions sufficiently rewarded by the innovator's head start should not be patentable. Since these innovations would exist anyway, I reasoned, there is no reason to pay the cost of the patent monopoly. The courts should use the non-obviousness test, I wrote, 'to evaluate the magnitude of the costs involved in a given innovation.' 30

Perhaps the rationalisation argument can be made again on the basis of differentiated patent policy, namely, that certain types of product sectors do

29 P. Menell and S. Scotchmer, 'Intellectual Property' in M. Polinsky and S. Shavell (eds), Handbook of Law and Economics, vol. 2 (Amsterdam: Elsevier, 2007) 1473-1570.

30 Kitch, n. 18 above, 281. 
require utility model protection as they are more concerned with incremental or improvement innovation. For example, the European Commission argued for the introduction of a pan-EU utility model law as it felt there was a need for a rapid and cheap protective regime for minor innovations in the following industries: toy manufacturing, clock and watchmaking, optics, microtechnology and micromechanics. A more recent 2015 study acknowledges this view. The picture in the wider public has therefore emerged of the utility model being an IP tool for the 'small inventor and his/her small inventions'. ${ }^{31}$

National policymakers who wish to introduce utility model laws on this basis should note that much is dependent on the economic status of the country in question. For example, what is the percentage of SMEs within the country or region? How much innovation that is important to that region's economy emanates from these SMEs? It may be that many innovations emanate from SMEs as opposed to from larger multinational conglomerates, or that SMEs have a heavy presence in small or emergent industries that are concerned not so much with revolutionary technological breakthroughs, but more so with cumulative innovation. If this is so, it is important to gauge whether the current national patent regime is attuned to the needs of SMEs and the types of inventions they produce. In the recent 2015 report on the economic impact of utility model laws in the EU, it was shown that SMEs did not use utility model as a primary protection tool - instead, the function of utility model was as an 'auxiliary IP tool in environments where patents are important' ${ }^{32}$ This may be the case in mature economies, but can this conclusion be transplanted to emerging and developing nations?

\subsection{Improving the Legal Environment in Developing Countries}

It has been asserted that patent protection certainly contributes to innovation and economic growth in developed countries, but not necessarily in developing countries. This is ascribed to the fact that patent protection tends to be useful within industrial activities only after countries have achieved a threshold level

\footnotetext{
31 A. Radauer, C. Rosemberg, O. Cassagneau-Francis, H. Goddar and C.-H. Haarmann, 'Study on the economic impact of the utility model legislation in selected Member States - Final Report', Study of Technopolis \& Boehmert on behalf of the European Commission (February 2015) available at https://publications.europa.eu/en/ publication-detail/-/publication/830fedd7-a1cf-46bd-a460-ba4a9eb01e63 (accessed 30 September 2018).

Ibid., 18.
} 
of indigenous innovative capacity, accompanied by an extensive science and technology infrastructure. ${ }^{33}$

A recurrent rationale for utility models is that this right would be especially beneficial for developing countries seeking to advance their technological capacities through local innovation by SMEs. For example, Juma put forward five reasons why utility models are appropriate for many developing countries. The first is that they enable artisans to secure protection for innovations that do not meet the stricter novelty and inventive step requirements of patent law. Developing economies, with their cottage and fledgling industries, may produce more incremental innovations. Second, they make it possible to increase the role of small scale innovators and artisans in economic development and help them stay in business in the face of new technologies that might threaten their livelihoods. Third, they act as a spur to enhanced levels of innovation. Fourth, they are cheaper to acquire than patents. And finally, they may become a source of data on innovative activity and experience in technological management. ${ }^{34}$

Indeed, national industries have complained that indigenous innovation is vulnerable to unfair copying by foreign competitors and that the unavailability of protection robs them of the vital lead time required to recoup research and development costs. The solution is to either lower the thresholds of patent protection - which may be impossible due to international or bilateral trade obligations - or to introduce a second tier of protection aimed specifically at encouraging local and/or incremental innovation.

While all the rationales are plausible, from both developed and developing perspectives, it is difficult to gauge the success of utility model laws based solely on justificatory bases. We can attempt to draw some conclusions if we turn to look at some national case studies.

33 Y.K. Kim, K. Lee, W.G. Park and K. Choo, 'Appropriate intellectual property protection and economic growth in countries at different levels of development' (2012) 41 Research Policy 358, 359, citing L. Kim, Imitation to Innovation: The Dynamics of Korea's Technological Learning (Boston: Harvard Business School Press, 1997).

34 C. Juma, The Gene Hunters: Biotechnology and the Scramble for Seeds (Princeton: Princeton University Press, 1989) 231-32. 


\section{LEGAL TRANSPLANTS AND EXPERIMENTS}

\subsection{Correlation between Utility Models and National Innovative Capacity}

A well cited study by Kumar found that in East Asian countries (namely, Japan, South Korea and Taiwan), a combination of relatively weak IPR protection and the availability of second tier patents such as utility models and design patents encouraged technological learning in their developmental years. ${ }^{35}$ The weak IPRs helped by allowing for local absorption of foreign innovations and R\&D spillovers. Second tier systems encouraged minor adaptations and inventions by local firms. Consequently, such economies became stronger, partly because local technological capacity was sufficiently advanced to generate a significant amount of innovation, and also as a result of international pressure. The report situates India's experience as being somewhat similar, except that in that case, no second tier protection was provided. While this apparently did not harm the growth of Indian chemical or pharmaceutical industries, it may have hindered the development of innovative engineering industries. ${ }^{36}$

Similarly, the study by Kim et al in relation to Korean firms and indigenous technological development noted that

utility model innovations contribute to firm performance when firms are technologically lagging and that those minor innovations can be a learning device and thus a stepping stone for developing more patentable inventions later on. Upon reaching higher levels of technological capabilities, firms become more reliant upon patents and less on utility models. Thus the lesson here is that patent protection enhances innovation and economic growth in countries where the capacity to conduct innovative research exists. Where this capacity is weaker, a system that provides incentives to conduct minor, incremental inventions is more conducive to growth. ${ }^{37}$

This study concludes that strong IPRs do not necessarily lead to development, but that countries have to tailor their regime to pick the appropriate cocktail of IPRs that will suit the national innovative and economic environment. ${ }^{38}$

35 N. Kumar, 'Intellectual Property Rights, Technology and Economic Development: Experiences of Asian Countries' (2003) 38(3) Econ. \& Pol. Weekly 209, 211-12; D. Prud'homme, "Utility model patent regime "strength" and technological development: experiences of China and other East Asian latecomers' (2017) 42 China Econ. Rev. 50, also available at https://papers.ssrn.com/sol3/papers.cfm?abstract_id= 2892130 (accessed 30 September 2018).

$36 \quad$ Kumar, n. 35 above, 211-12.

37 Kim, Lee, Park and Choo, n. 33 above, 358 (abstract).

38 Ibid., 358-75. 
A more recent 2013 Australian economic review confirmed that the economic effect of utility models decreases with the rise of technological capacity in industries; the report concluded, however, that the continued use of utility models in Japan, Germany, France and Italy suggests that these patents may have a role in innovation and economic growth even in developed economies. ${ }^{39}$

Other studies similarly note that countries do tailor their patent and utility model regimes as part of national innovation policies. The studies also show that developing economies can have mixed results due to changing national policies: on the one hand, utility model and patent laws are transplanted from other, more mature legal regimes, and then countries are faced with the task of transforming such laws to meet evolving local needs of the recipient country. Thus, patent regimes have been weakened in certain countries in order to shift low income economies into the middle income stages. ${ }^{40}$ Conversely, technologically strong and developed economies begin to distrust an 'easy' system and switch to more rigorous patent and utility model regimes, as their concerns shift to competitiveness, the need to attract foreign direct investment and the use of the utility model system by foreign companies (see the discussions below on Australia and Japan). ${ }^{41}$

\subsection{China and Japan}

The notion of transplantation and change has been claimed to be most visible in China. ${ }^{42}$ Utility model protection is accorded to 'any new technical solution relating to the shape, structure, or their combination, of a product, which is fit for practical use'. ${ }^{43}$ The standard for inventiveness is lower than that required

39 J. Zeitsch, 'The economic value of the Australian Innovation Patent: The Australian Innovation Patent Survey', Verve Economics (24 March 2013) available at www.ipaustralia.gov.au/sites/g/files/net856/f/economic value of the innovation_patent_-_final_report_-_verve_economics_-_24 mar_2013.pdf (accessed $\overline{3} 0$ September 2018).

$40 \quad$ Prud'homme, n. 35 above, citing many empirical studies, but of note is that by K. Maskus and M Penubarti, 'How trade-related are intellectual property rights?' (1995) 39 J. Int'l Econ. 227-48.

$41 \quad$ Kim, Lee, Park and Choo, n. 33 above, 358-75.

42 Prud'homme, n. 35 above; P. Yu, 'Intellectual property, economic development, and the China puzzle' in D. Gervais (ed.), Intellectual Property, Trade and Development: Strategies to Optimize Economic Development in a TRIPs Plus Area (Oxford: Oxford University Press, 2007) 173-220; N. Lee, 'Intellectual property law in China - From legal transplant to governance' in N. Lee, N. Bruun and M. Li (eds), Governance of Intellectual Property Rights in China and Europe (Cheltenham, UK and Northampton, MA: Edward Elgar, 2016) 5-19.

$43 \quad$ Art. (2) PRC Implementing Regulations of 12 December 1992, entry into effect on 1 January 1993. 
for patents, and applications are examined ex officio as to compliance with formalities only. ${ }^{44}$ The positive impact of the utility model regime on China has been strenuously claimed [as the following quotes show]:

'increased usage of utility models in China in particular contributed to rising labor productivity in the country'

'utility models in mainland China had a significant impact on [total factor productivity] from 1988 to 1998, and from 1999 to 2009 both invention patents and utility models had significant impacts on TFP (although invention patents had stronger impacts than utility models';

'individual inventors and SMEs in particular, although also large companies to some extent, in China have benefited from technological learning opportunities afforded by using utility models'. ${ }^{45}$

On the other hand, some commentators believe that despite its value, the utility model system in China is problematic. The absence of examination makes it especially difficult to guarantee the quality or level of inventiveness involved in a utility model and consequently, disputes have occurred. It is suggested that this could only be resolved by providing a corresponding search report. ${ }^{46}$ Moreover, it has been alleged that utility models are granted to local 'inventors' for inventions imported from overseas and that the local owners sometimes assert their rights against the original inventors. ${ }^{47}$

Much does depend on the innovation culture of the country. Take Japan, for example. It was the first Asian country to introduce utility model protection, with its system dating from 1905 and directly transplanted from German law. It is undoubtedly a prime example of a country that used utility models to improve its technological capacity and boost its indigenous incremental innovation, but markedly changed the structure in order to suit an increasingly

44 Art. 22(3) PRC Patent Law of 12 March 1984, entry into effect on 1 April 1985, amended in September 1992.

45 Prud'homme, n. 35 above, 9 (citing several empirical studies from 2002 to 2011).

${ }_{46}$ S. Guo, 'The Development and Perspective of Intellectual Property in the People's Republic of China', (1997) IPQ 151; also see Heath, n. 3 above, 47-72, discussing the salient aspect of the Chinese utility model system.

$47 \quad$ Suthersanen, 'Utility Models and Innovation in Developing Countries', n. 3 above, 39; B. Spurgeon, 'The new Chinese counterfeit game', International Herald Tribune (14 November 2004). Abuse of the utility model system is also reported in the United States International Trade Commission Report, China: Intellectual Property Infringement, Indigenous Innovation Policies, and Frameworks for Measuring the Effects on the U.S. Economy (2010) available at www.usitc.gov/publications/332/ pub4199.pdf (accessed 30 September 2018). 
higher innovative climate. ${ }^{48}$ There has been a steady drop in applications for registrations, as Figure 1.1 shows: from approximately 191,000 (1980), to 77,000 (1993), to 10,000 (1999). ${ }^{49}$

Various reasons can be suggested for this. First, the Japanese government revised the utility model law and introduced a 'no examination' rule, while curtailing the duration of protection from ten to six years. One commentator states that these revisions constituted barriers to obtaining injunctive relief, and a loss of confidence as to the validity of nonexamined rights. ${ }^{50}$ Second, the amount of patents applied for increased during the same period from 1980 to 1999, suggesting a shift in the Japanese innovation culture from incremental innovation (from the immediate postwar years to the 1980s), to more radical innovation thereafter. ${ }^{51}$

Finally, the patent regime was reformed in 1987 to eliminate the single claim requirement, thus making the patent regime more attractive. ${ }^{52}$ Maskus and McDaniel suggest that the utility model experiment in Japan was extremely important as it bolstered 'technology diffusion through utility model applications'. Thus, they conclude, utility models

had a positive impact on Japan's post-war productivity growth. Further, there was an important indirect impact of applications for invention patents, reflecting more fundamental industrial invention, through their stimulation of follow-on utility model applications, which were quickly diffused into commercial use. ${ }^{53}$

48 H. Odagiri, A. Goto, A. Sunami and R. Nelson, 'Introduction', in H. Odagiri, A. Goto, A. Sunami and R. Nelson (eds), Intellectual Property Rights, Development, and Catch-Up - An International Comparative Study (Oxford: Oxford University Press, 2010) 1-28. See also Prud'homme, n. 35 above, citing K.S. Kardam, 'Utility model a tool for economic and technological development: a case study of Japan', WIPO and Japanese Patent Office (2007) available at www.ipindia.nic.in/writereaddata/images/ pdf/FinalReport_April2007.pdf (accessed 30 September 2018) (showing that the utility model system in Japan enabled improved technological diffusion and learning that lead to incremental innovation).

49 WIPO Annual Statistics, Utility model filing in Japan; Japan Patent Office, Annual Report 2000, Patent Filing in Japan.

50 C. Heath, 'Utility model law' in Encyclopedia of Japanese Law from 1868 (Leiden, Netherlands: Brill Publishing, 2002). Parties have the possibility of requesting Technical Opinions, especially prior to commencing infringement proceedings. Japanese Utility Model Act No 123 of 1959, as amended in 2006. See M. Macdonald, S.M. Maniatis and U. Suthersanen, Design and Copyright Protection of Products: World Law \& Practice (London: Sweet \& Maxwell, 1997) p.JAPAN-9.

${ }_{51}$ E. Mansfield, 'Industrial R\&D in Japan and the United States: a comparative study' (1988) 78 Am. Econ. Rev. 223; Heath, n. 50 above.

${ }_{52}$ K.E. Maskus and C. McDaniel, 'Impacts of the Japanese patent system on productivity growth' (1999) 11(4) Japan and the World Economy 557-74.

53 Ibid. 


\section{Number of Patent and Utility Model Applications}

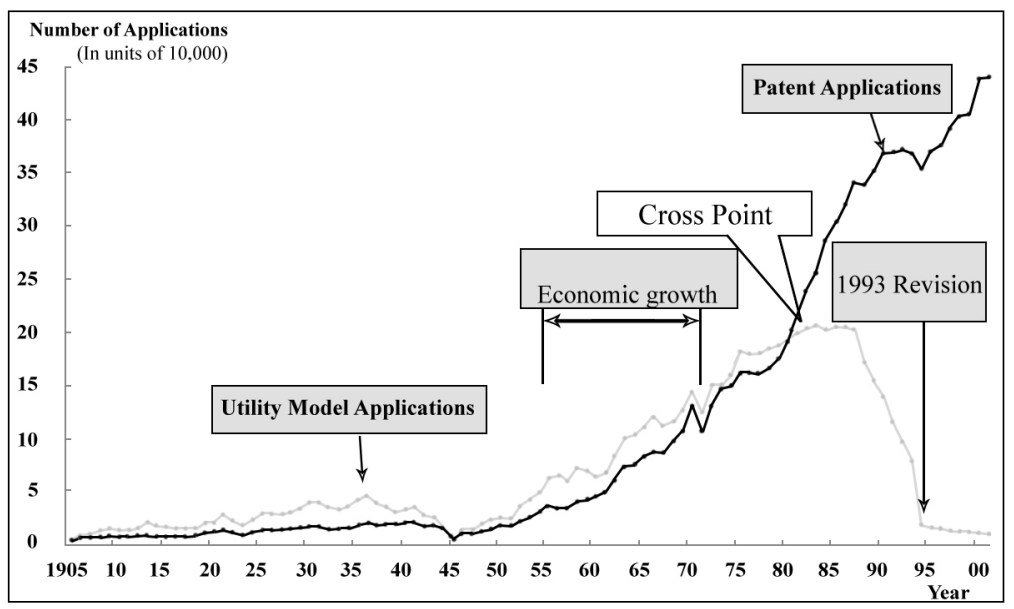

Note: Number of patent and utility model applications in Japan. Source: Japanese Patent Office.

Figure 1.1 Number of patent and utility model applications in Japan

We now turn to another national transplant experiment, which has had very mixed results.

\subsection{The Australian Paradox: A 33-Year Experiment}

The Australian experience is instructive in revealing how conceptually slippery the transplantation, construction and judicial implementation of second tier laws can be in relation to innovation.

\subsubsection{Introducing the petty patent from 1979}

Australian national intellectual property policy embraced the second tier scheme in 1979, when the 'petty patent' was introduced as a specific form of protection for indigenous inventions with a short commercial life. The key features were: universal novelty but with a local prior art examination; a six-year term of protection; specific exclusion of process and chemical/biochemical inventions; and a limited scope of protection. This was, thus, a classic utility model right.

The origins of the petty patent system lay in dissatisfaction with the design right system, which did not protect functional designs. The legislature decided 
Table $1.1 \quad$ Comparison of patent and petty patent applications in Australia

\begin{tabular}{lll}
\hline YEAR & $\begin{array}{l}\text { STANDARD PATENT } \\
\text { APPLICATION }\end{array}$ & $\begin{array}{l}\text { PETTY PATENT } \\
\text { APPLICATION }\end{array}$ \\
\hline 1994 & 7331 & 389 \\
1996 & 9196 & 251 \\
\hline
\end{tabular}

that a petty patent system was necessary to contribute to an environment of growth within the national boundaries - one rationale was that it would encourage small business to invest and operate in another market; another was that the regime would help limit importation of copies. This conclusion was partly due to the nature of the Australian economic infrastructure, as it was a net importer of technology and much innovation was based on improvements and innovative effort. ${ }^{54}$

However, the system has had limited success in meeting its intended objectives. Although the main users of the petty patent system are Australian individuals and SMEs (70 per cent), the number of applications made for petty patents, as Table 1.1 reveals, remained small. Filing statistics for Australia show that between 200 and 400 petty patent applications were filed each year, from which 50-60 per cent of the applications proceeded to the grant stage. One dissatisfaction with the system was that the requirement of inventiveness was similar to that of a standard patent.

After a governmental consultation and review of the system, the decision was made to retain the second tier system but to tailor the law to meet the expectations of the local industry, and to foster more indigenous innovation, especially in relation to the level of inventiveness, the duration of the right and the scope of prior art. ${ }^{55}$ Thus, in 2001, the second tier system was revised to lower the threshold of inventiveness, and the system was reestablished as the 'innovation patent' system.

One clear conclusion from the governmental review was that it was not at all clear whether the petty patent system fostered indigenous invention; nonetheless, the sui generis right was recommended for the following reasons:

On the other hand, by maintaining a system that promotes local market activity we can contribute to an environment of growth within our own borders. The trickle

54 Advisory Council on Industrial Property, 'Review of the Petty Patent System' (Australian Industrial Property Organisation, October 1995) 24 ff., available at www.ipaustralia.gov.au/sites/g/files/net856/f/acip_final_report_review_of_petty _patent_system_archived.pdf (accessed 31 August 2017).

Ibid., ch. 5. 
down effect of offering protection in one market may provide strength and encouragement to a business to operate in another market and may be the forerunner to export activity. In addition, the existence of the local system will help limit the importation of copies..$^{56}$

As stated before, much depends on the country's perceived needs and in the case of Australia, the review conclusions do make sense. Here is a region that is a net importer of intellectual property goods, with a strong case to curtail imports of foreign goods by encouraging the local industry society. Moreover, the low filing figures clearly called for a system change, as we see below.

\subsubsection{The innovation patent from 2001}

The review of the patent systems brought changes to the second tier regime, and the innovation patent system was born. The name change was thought to be crucial to signal to Australian users that a new regime was in place which now called for universal novelty and 'innovative' step and which extended protection to all types of technologies. The newly reformed innovative step was formulated as follows:

an invention is to be taken to involve an innovative step when compared with the prior art base unless the invention would, to a person skilled in the relevant art, in the light of the common general knowledge as it existed in the patent area before the priority date of the relevant claim, only vary from the kinds of information set out in subsection (5) in ways that make no substantial contribution to the working of the invention. ${ }^{57}$

As regards registration figures, the system appeared to have been robust with 15,170 innovation patents filed from the inception of the innovation patent system in 2001 until the end of 2013. Over this period, on average, 23 per cent of these patents were filed by foreign applicants, 47 per cent by Australian individuals and 30 per cent by Australian companies or firms. ${ }^{58}$

Why was the system challenged again a decade later? In 2011, the Australian government called for yet another report, which was released in 2015. The 2015 report by the Australian Intellectual Property Council could not make a recommendation supporting the retention or abolition of the current system, but pointed out various concerns.

$56 \quad$ Ibid., 15-16.

$57 \quad$ Sec. 7 Patents Act.

58 Australian Government's Advisory Council on Intellectual Property, 'Review of the Innovation Patent System - Final Report' (May 2015) 28, available at www.ipaustralia.gov.au/sites/g/files/net856/f/final_report.pdf (accessed 30 September 2018). 
A primary concern was that the system was being used for strategic or tactical purposes to protect higher level inventions, rather than to stimulate innovation within SMEs. The increase in filing was believed to be due to the 2008 Federal Court of Australia's decision in Delnorth that dealt with the crucial concept of innovative step. The Court determined that the threshold for innovation patents was set lower than the threshold for standard patents. While this was something that was anticipated by the legislature and the industry, the Court went further to hold that an 'innovative step' allows even obvious enhancements to be patented. ${ }^{59}$ With such a low level of innovation required, the 2015 report highlighted several resulting fault lines within the system, including evergreening practices, since the low threshold allows certain users to extend the effective term of the patent monopoly of a previously patented invention by claiming for obvious or very incremental modifications; and developing patent thickets by filing divisional innovation patents for minor (and obvious) variants of the main patented invention, leading possibly to more time and expense involved in opposition applications. ${ }^{60}$

A final concern was the rise of innovation patent applications in particular technological areas - specifically, electrical devices and engineering (a 350 per cent rise), information technology (a 390 per cent rise) and pharmaceuticals (a 560 per cent rise). This compares to a rise in applications of 150 per cent averaged over all technologies. ${ }^{61}$ The 2015 Australian Advisory Council on IP concluded that it was 'unable to obtain adequate empirical evidence as to whether the system does or does not stimulate innovation in Australian SMEs' ${ }^{62}$

Table 1.2 sets out briefly the different faults discovered in the two very different second tier regimes in Australia within two decades.

\subsubsection{Abolishing the innovation patent? The 2016 review}

The 2015 Advisory Council Report sets out a list of highly pertinent conclusions and queries for countries considering introducing the utility model regime. For instance, the report stated that the continuation of the system will not guarantee that in the long run Australian SMEs will be the primary beneficiaries of such protection - as foreign companies were increasingly

\footnotetext{
$59 \quad$ Dura-Post (Aust) Pty Ltd v Delnorth Pty Ltd [2009] FCAFC 81.

60 The Report cited the following decisions as being indicative of the problems being faced: Britax Childcare Pty Ltd v Infa-Secure Pty Ltd [2012] FCA 467; Apple Inc. v Samsung Electronics Co. Limited [2011] FCA 1164; [2011] FCAFC 156 (on appeal); Britax Childcare Pty Ltd v Infa-Secure Pty Ltd, No 3 [2012] FCA 1019. See 2015 Advisory Council Report, n. 55 above, 36-39.

${ }_{61}$ Australian Government - IP Australia, 'Innovation Patents - Raising the Step', Consultation Paper (2012).

2015 Advisory Council Report, n. 55 above, 8.
} 
Table 1.2 Review of alternative utility model systems

\begin{tabular}{|c|c|c|}
\hline DIFFERENCES & PETTY PATENTS & INNOVATION PATENTS \\
\hline Subject matter & Identical to standard patents & $\begin{array}{l}\text { No protection for inventions concerning } \\
\text { plants/animals/processes for generation } \\
\text { of them }\end{array}$ \\
\hline $\begin{array}{l}\text { Subject matter and } \\
\text { criteria of protection }\end{array}$ & $\begin{array}{l}\text { Identical to standard patents, } \\
\text { substantive examination }\end{array}$ & $\begin{array}{l}\text { Lower threshold of criterion - 'innovative } \\
\text { step', no substantive examination }\end{array}$ \\
\hline Duration & 6 years maximum & 8 years maximum \\
\hline $\begin{array}{l}\text { Opposition } \\
\text { proceedings }\end{array}$ & $\begin{array}{l}\text { Available prior to grant and limited } \\
\text { examination process }\end{array}$ & $\begin{array}{l}\text { No opposition proceedings prior to } \\
\text { grant and no examination (except at } \\
\text { enforcement stage) }\end{array}$ \\
\hline Scope of protection & Limited to 3 claims & Limited to 5 claims \\
\hline $\begin{array}{l}\text { Disadvantages of } \\
\text { the regime }\end{array}$ & $\begin{array}{l}\text { Too expensive - cost was the same as } \\
\text { standard patents } \\
\text { Too short a duration of protection } \\
\text { Difficult to enforce a single claim } \\
\text { Minor innovations cannot fulfil } \\
\text { inventive step } \\
\text { Too little usage - } 300 \text { applications } \\
\text { per year }\end{array}$ & $\begin{array}{l}\text { (i) Too low threshold - Delnorth decision } \\
\text { held that innovative step allows clearly } \\
\text { obvious enhancements to be patented } \\
\text { (ii) Tactical use of regime, especially in } \\
\text { certain industries, creates uncertainty and } \\
\text { blocks follow-on innovation } \\
\text { (iii) Potential for evergreening and 'patent } \\
\text { thickets' } \\
\text { (iv) Fear of Australian system falling into } \\
\text { disrepute }\end{array}$ \\
\hline
\end{tabular}

taking advantage of the innovation patent system. In such circumstances, it would become difficult to identify the market failure that an innovation patent is addressing.

More challenging is its final concern as to whether the system costs more than the benefits it generates:

Which incremental technological developments will not occur if protection is not given via a level of innovation approach as opposed to a level of invention approach? Alternatively, which of such developments will not be worked in Australia as a consequence of a lack of protection at the sub-patent level? On the other hand, if other incremental technological developments are stymied by innovation patents and those developments that do receive an innovation patent would have occurred in any event without the grant of such protection, the Australian economy would be incurring costs without obtaining any significant countervailing benefit. ${ }^{63}$ 
Even more damning was a subsequent 2016 Report released by the Australian Productivity Commission, which recommended abolishing the innovation patent system. ${ }^{64}$ Some of the reasons were:

(1) the low innovative step increases low value patents, as there was a very low distribution of private value of innovation patents;

(2) the innovation patent system did not target additional innovation as none of the previous studies and reports showed that the absence of a second tier system did not necessarily mean that the innovation would not have occurred;

(3) low value patents create uncertainty, increase noise and promote divisional patent application leading to patent thickets, hence making it difficult to see how the system promotes innovation by SMEs as it would increase costs for users and stunt innovation; and

(4) the benefits of the innovation patent system may be illusory or not as large as thought, especially in relation to costs - indeed, this is one of the most flaunted aspects of the second tier patent, and yet the Australian empirical evidence suggests that the upfront and maintenance costs for innovation and standard patents are similar.

\section{$5 \quad$ CONCLUSION}

This chapter looked at the concept of utility model across several jurisdictions and through multiple timelines. It is clear that one can justify introducing a new hybrid intellectual property right on several grounds. On the other hand, national case studies do indicate that the utility model system is very much a localised phenomenon. The lesson learned from the different regimes is that it is difficult to determine the contours of protection, especially in relation to the level of inventiveness required and the level of substantive examination.

Based on an analysis of various studies, it certainly is true that utility model protection may enhance or stimulate the behaviour of small and medium sized enterprises. This may in turn encourage higher economic performance and develop the innovative capacity of certain economies at specific stages of their

64 Australian Government - Productivity Commission 2016, 'Intellectual Property Arrangements', Inquiry Report No 78 (23 September 2016) available at: www.pc.gov.au/inquiries/completed/intellectual-property/report/intellectual-property -overview.pdf (accessed 30 September 2018). See especially ibid., 248-58, citing various preceding reports and studies, including the UK Gowers Review of Intellectual Property. 
development. Indeed, minor innovations may be a stepping stone for developing more patentable inventions.

Conversely, it is arguable that utility model protection may be the most appropriate mechanism to allow 'developing economies to build up their indigenous innovative capacities'. ${ }^{65}$ However, once the innovative capacity of the country has been reached, and when the national economy and its industries reach higher levels of technological capacity, as in Japan and certainly Australia, it does appear that the disadvantages outweigh the perceived advantages.

Should there be further research in this area? Should we construct model frameworks or laws for countries to transplant and adapt? As the Japanese and Australian case studies show, the problem is that the cost-benefit analysis from both the legal and economic perspective tends to be firmly anchored to the national innovation capacity. There are reasonable arguments for the importance and usefulness of utility model systems in developing countries, and the Chinese, German and South Korean experiences show that it is appropriate for certain countries. Nevertheless, the empirical evidence gathered in a multitude of studies all suggest that the task of modelling an optimal utility model regime, taking into account the different stages of development, will ultimately prove to be a highly complex and possibly futile task. 